\title{
A Case Report of a Japanese Boy with Morquio A Syndrome: Effects of Enzyme Replacement Therapy Initiated at the Age of 24 Months
}

\author{
Akari Nakamura-Utsunomiya ${ }^{1, *(D)}$, Toshio Nakamae ${ }^{2}$, Reiko Kagawa ${ }^{1}$, Shuhei Karakawa ${ }^{1}$, \\ Sonoko Sakata $^{1}$, Fumiaki Sakura ${ }^{1}$, Chihiro Tani ${ }^{3,4}$, Yoshiko Matsubara ${ }^{3}$, Takashi Ishino ${ }^{5}$, \\ Go Tajima ${ }^{1,6}$ and Satoshi Okada ${ }^{1}$ (D) \\ 1 Department of Pediatrics, Hiroshima University Graduate School of Biomedical and Health Sciences, \\ Hiroshima 7348511, Japan; ykagawa@ja2.so-net.ne.jp (R.K.); kara1224@hiroshima-u.ac.jp (S.K.); \\ sonokosakata1116@yahoo.co.jp (S.S.); d185866@hiroshima-u.ac.jp (F.S.); tajima-g@ncchd.go.jp (G.T.); \\ saok969@gmail.com (S.O.) \\ 2 Department of Orthopeadic Surgery, Graduate School of Biomedical and Health Sciences, \\ Hiroshima University, Hiroshima 7348551, Japan; nakamaet@hiroshima-u.ac.jp \\ 3 Department of Diagnostic Radiology, Hiroshima University Hospital, Hiroshima 7348551, Japan; \\ ctani620@gmail.com (C.T.); matsuys@hiroshima-u.ac.jp (Y.M.) \\ 4 Department of Diagnostic Radiology, Hiroshima Citizen's Hospital, Hiroshima 7308518, Japan \\ 5 Department of Otolaryngology, Hiroshima University Hospital, Hiroshima 7348551, Japan; \\ tishino@hiroshima-u.ac.jp \\ 6 Division of Neonatal Screening, Research Institute, National Center for Child Health and Development, \\ Tokyo 1578535, Japan \\ * Correspondence: akari-ped@hiroshima-u.ac.jp
}

Received: 29 December 2019; Accepted: 27 January 2020; Published: 2 February 2020

check for updates

\begin{abstract}
Background: Morquio A syndrome, mucopolysaccharidosis type IVA (MPS IVA), is a lysosomal storage disorder caused by the deficient activity of $\mathrm{N}$-acetylgalactosamine-6-sulfatase (GalNac6S), due to alterations in the GALNS gene. This disorder results in marked abnormalities in bones and connective tissues, and affects multiple organs. Here, we describe the clinical course of a Japanese boy with MPS IVA who began enzyme replacement therapy (ERT) at the age of 24 months. Patient: the patient presented for kyphosis treatment at 22 months of age. An X-ray examination revealed dysostosis multiplex. Uronic acids were elevated in the urine and the keratan sulfate (KS) fraction was predominant. The leukocyte GalNac6S enzyme activity was extremely low. The patient exhibited the c.463G > A (p.Gly155Arg) mutation in GALNS. Based on these findings, his disease was diagnosed as classical (severe) Morquio A syndrome. An elosulfase alfa infusion was initiated at the age of 24 months. The patient's body height improved from -2.5 standard deviation (SD) to $-2 \mathrm{SD}$ and his physical activity increased during the first 9 months on ERT. However, he gradually developed paralysis in the lower legs with declining growth velocity, which required cervical decompression surgery in the second year of the ERT. The mild mitral regurgitation, serous otitis media, and mild hearing loss did not progress during treatment. Conclusion: early initiation of the elosulfase alfa to our patient showed good effects on the visceral system and muscle strength, while its effect on bones appeared limited. Careful observation is necessary to ensure timely surgical intervention for skeletal disorders associated with neurological symptoms. Centralized and multidisciplinary management is essential to improve the prognosis of pediatric patients with MPS IVA.
\end{abstract}

Keywords: Morquio A syndrome; mucopolysaccharidosis type IVA; elosulfase alfa; enzyme replacement therapy; growth; spinal decompression surgery 


\section{Introduction}

Mucopolysaccharidosis type IVA (MPS IVA) (Morquio A syndrome, OMIM \#253000) is an autosomal recessive lysosomal storage disease, characterized by the accumulation of keratan sulfate (KS) and chondroitin-6-sulfate, which is caused by homozygous or compound heterozygous mutations in the GALNS gene encoding N-acetylgalactosamine-6-sulfatase (GalNac6S) [1]. Because chondroitin-6-sulfate and KS are mainly produced in cartilage [2], the storage of glycosaminoglycan (GAG) within the lysosomes disrupts cell function and metabolism in cartilage [3]; this disruption results in a direct impact on cartilage and bone development, ossification failure, growth imbalance, and unique systemic skeletal dysplasia [4-6]. An excessive accumulation of KS in the lysosomes reportedly results in the inhibition of bone formation in osteoblasts [7]. Abnormal chondrogenesis and osteogenesis (dysostosis multiplex) [3] are largely responsible for the typical phenotype of affected patients, including short stature, kyphoscoliosis, prominent bell/barrel-shaped chest, frontal bossing, genu valgum and joint laxity [8,9]. However, intelligence is normal and there is no direct central nervous system involvement, in contrast to the phenotype of other MPS, such as Hurler syndrome and Hunter syndrome. The prevalence of MPS IVA in previous reports (determined using recommended diagnostic methods) ranges from 1 per 71,000 in the United Arab Emirates to 1 per 500,000 in Japan [10].

Elosulfase alfa (Vimizim ${ }^{\circledR}$, BioMarin Pharmaceutical Inc., San Rafael, CA, USA) was approved in Japan in 2015 for use as an ERT for patients with MPS IVA. Previous reports showed that the ERT with elosulfase alfa is well tolerated and produces a reduction in the urine KS [11]. In an initial short-term study, positive effects on growth have been suggested [12]; however, the impact on bone growth has not been proved in the long term (over 2 years) $[13,14]$. In addition, the clinical information remains limited regarding the clinical course of patients $<5$ years of age with MPS IVA and their treatment with elosulfase alfa [14]. In this report, we describe the clinical course of a patient with MPS IVA who received the ERT for 25 months, beginning at 2 years of age.

\section{Patient}

The patient was the third boy of non-consanguineous healthy Japanese parents. His two older brothers were both healthy. After an uneventful pregnancy, he was born at a gestational age of 41 weeks by natural delivery; his body weight was $3600 \mathrm{~g}(+1.5$ standard deviation [SD]) and his body height was $58 \mathrm{~cm}(+4.3 \mathrm{SD})$. He exhibited mild hearing loss on the left side during a neonatal screening, and developed serous otitis media in infancy. He demonstrated delayed walking and kyphosis around the age of 12 months. At the age of 16 months, he was examined at the orthopedic department at Hiroshima University Hospital. The examination results were suggestive of a systemic bone disease, therefore, the patient was referred to the pediatrics department at the age of 22 months, with a body height of $78.6 \mathrm{~cm}(-1.8 \mathrm{SD})$ and a body weight of $10.86 \mathrm{~kg}(-0.2 \mathrm{SD})$. A physical examination revealed no abnormal findings, except lumbar kyphosis, which was most prominent at the level of L1. The patient's mental development was normal, but his gross motor development was substantially delayed; he could walk alone for approximately $10 \mathrm{~m}$ and exhibited a duck-like gait. Routine blood tests did not reveal remarkable findings (Table 1 ). 
Table 1. The clinical findings from the first visit of a Japanese boy with mucopolysaccharidosis type IVA (MPS IVA).

\begin{tabular}{|c|c|c|}
\hline & Patients & References \\
\hline White blood cell count $(/ \mu \mathrm{L})$ & 7680 & $3.3 \sim 8.6 \times 10^{3}$ \\
\hline Red Blood cell count $(/ \mu \mathrm{L})$ & $4.58 \times 10^{6}$ & $4.35 \sim 5.55 \times 10^{\wedge} 6$ \\
\hline $\mathrm{Hb}(\mathrm{g} / \mathrm{dL})$ & 11.6 & 13.7 16.8 \\
\hline $\operatorname{PLT}(/ \mu \mathrm{L})$ & $327 \times 10^{3}$ & $158 \sim 348 \times 10^{3}$ \\
\hline AST(IU/L) & 30 & $13 \sim 30$ \\
\hline ALT(IU/L) & 15 & $10 \sim 42$ \\
\hline LDH(IU/L) & 239 & $124 \sim 222$ \\
\hline BUN(mg/dL) & 17.3 & $8 \sim 20$ \\
\hline $\mathrm{Cr},(\mathrm{mg} / \mathrm{dL})$ & 0.20 & $0.65 \sim 1.07$ \\
\hline $\mathrm{Na}(\mathrm{mEq} / \mathrm{L})$ & 139 & $138 \sim 145$ \\
\hline $\mathrm{K}(\mathrm{mEq} / \mathrm{L})$ & 4.4 & $3.6 \sim 4.8$ \\
\hline $\mathrm{Cl}(\mathrm{mEq} / \mathrm{L})$ & 107 & $101 \sim 108$ \\
\hline $\mathrm{Ca}(\mathrm{mg} / \mathrm{dL})$ & 5.0 & $4.3 \sim 5.2$ \\
\hline $\mathrm{P}(\mathrm{mg} / \mathrm{dL})$ & 4.9 & $2.5 \sim 4.7$ \\
\hline $\mathrm{CRP}(\mathrm{mg} / \mathrm{dL})$ & 0.02 & $<0.3$ \\
\hline ph (vein) & 7.484 & 7.35 7.45 \\
\hline $\mathrm{pCO} 2$ & 27.4 & $35 \sim 45$ \\
\hline $\mathrm{HCO} 3-$ & 20.3 & $22 \sim 24$ \\
\hline $\mathrm{BE}$ & -0.7 & $-3.0 \sim 3.0$ \\
\hline $\begin{array}{c}\text { Leukocyte GalNac6S } \\
\text { Activity(nmol/mg protein/17 h) }\end{array}$ & $<1.3$ & 104.6 \\
\hline Urine uronic acid $(\mathrm{mg} / \mathrm{g} \cdot$ creatinine $)$ & 166 & $29.7 \pm 13.3$ \\
\hline Fraction of KS (\%) & 13 & Not detected \\
\hline
\end{tabular}

\section{Method}

As with the confirmatory tests for MPS IVA, uronic acids in the urine and the enzymatic activity of GalNac6S in the leukocytes were measured by the methods described previously [15]. The results were further confirmed by the direct sequencing of the GALNS gene. In brief, all of the exons and flanking intronic regions were amplified using Tks Gflex DNA Polymerase (Takara Bio, Tokyo, Japan). The amplicons were purified using an ExoSAP-IT PCR Product Cleanup kit (Affymetrix Japan, Tokyo, Japan) and sequenced using a BigDye Terminator v3.1 Cycle Sequencing Kit and an Applied Biosystems 3130xl Genetic Analyzer (Thermo Fisher Scientific, Foster City, CA) [15].

\section{Diagnosis}

A whole-body $\mathrm{X}$-ray revealed the findings of multiple dysostosis, such as the anterior tongue of the vertebrae and a dumbbell-like deformity in the proximal and middle phalanges of the hands and feet (Figure 1). The spinal magnetic resonance imaging (MRI) showed a moderate compression at $\mathrm{C} 1$ level and mild constriction at the thoracolumbar transition (Figure 2). The concentration of uronic acids in

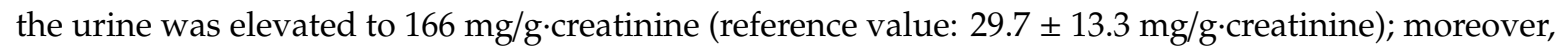
a KS fraction as high as $13 \%$ was predominant, which indicated MPS IVA. The leukocyte GalNac6S activity was below the determination limit $(<1.3 \mathrm{nmol} / \mathrm{mg} / 17 \mathrm{hr})$ (Figure 3). Sanger sequencing of the GALNS gene detected c.463 mcG > A (p.(Gly155Arg)), which was confirmed to be homozygous based on the absence of deletions in microarray analysis (Figure 3). Based on previous reports, this missense mutation is presumed to cause the classical (severe) phenotype of MPS IVA [10]. 

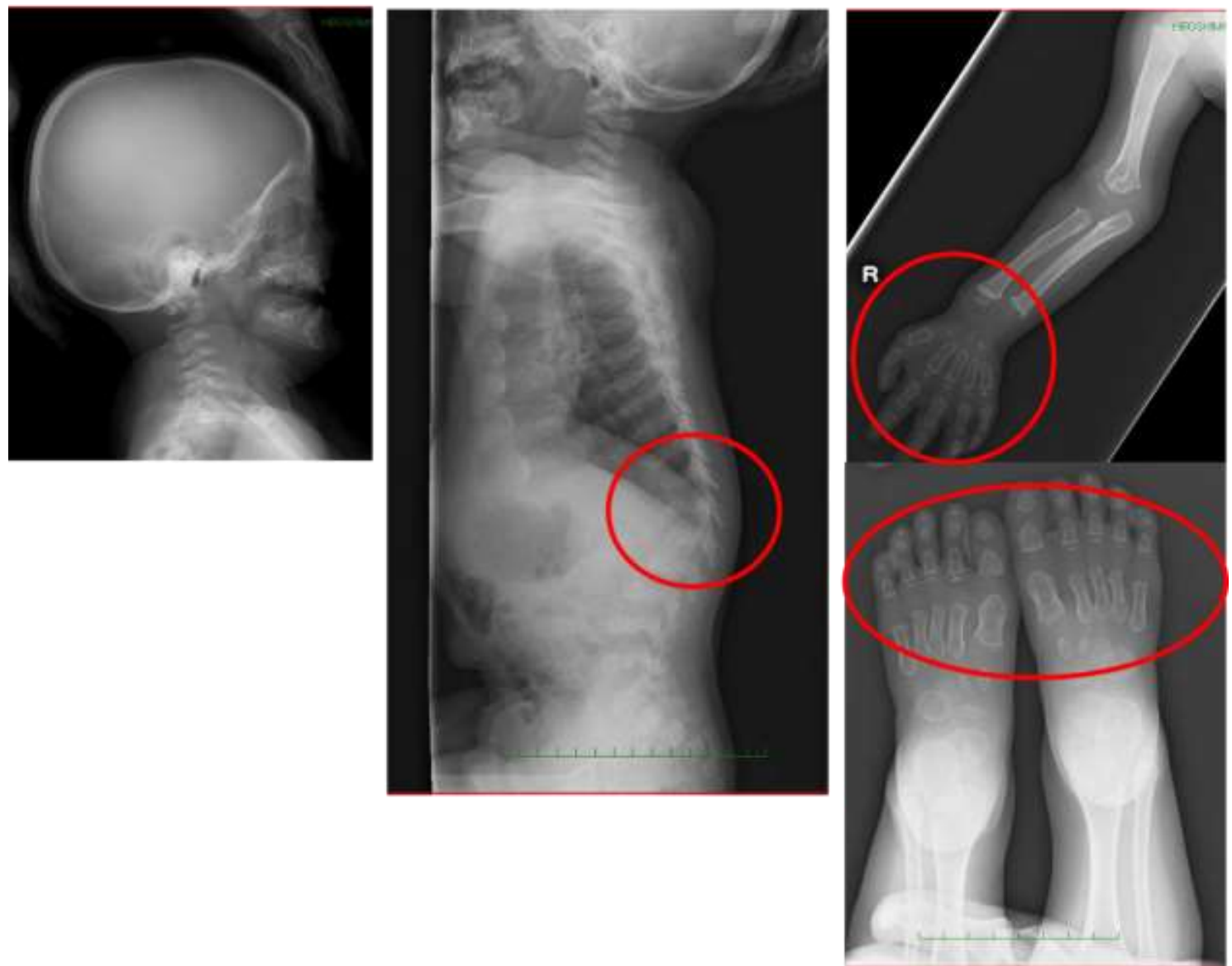

Figure 1. A whole-body X-ray from the first visit of a Japanese boy with MPS IVA. The findings of multiple dysostosis, such as the anterior tongue of the vertebrae and a dumbbell-like deformity in the proximal and middle phalanges of the hands and feet were observed.
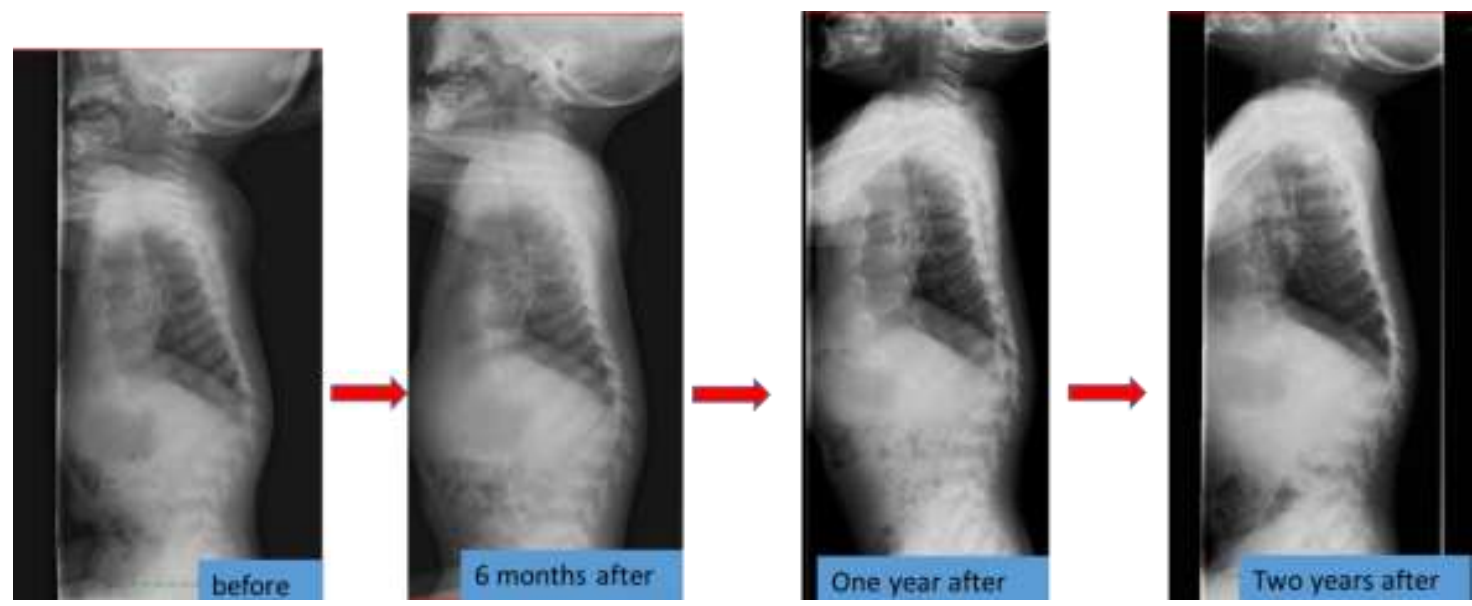

Figure 2. The spine $X$-ray findings before and after the enzyme replacement therapy in a Japanese boy with MPS IVA. 


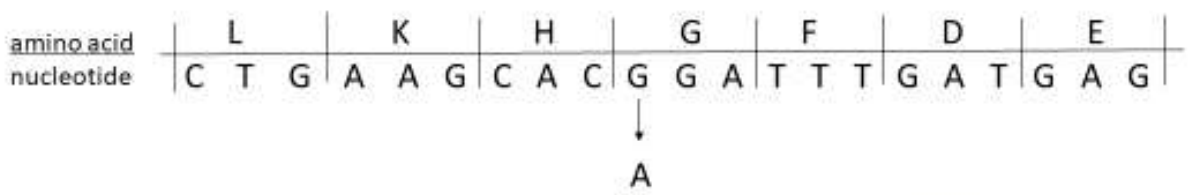

c.463G>A / p.G155R

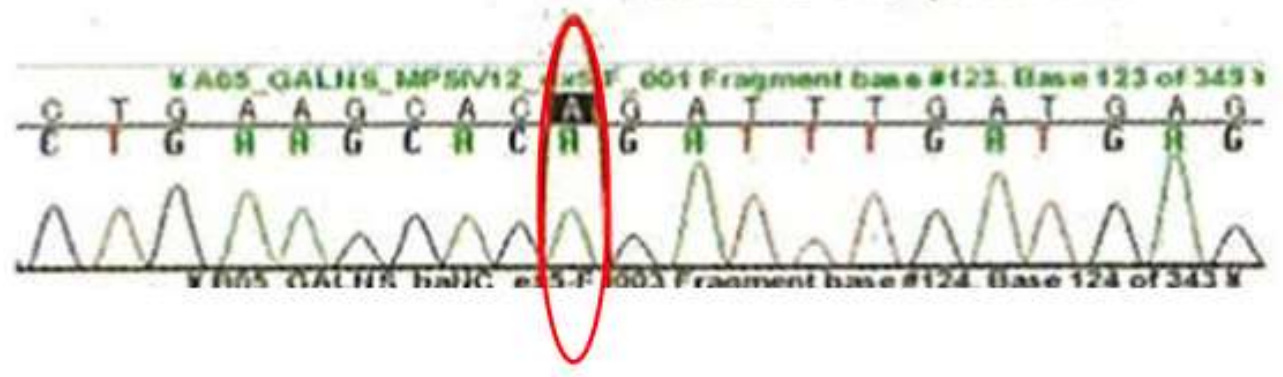

Figure 3. The genetic analysis of the GALNS gene in a Japanese boy with MPS IVA. Sanger sequencing of GALNS detected a homozygous variant c.463G > A (p.Gly155Arg).

\section{Enzyme Replacement Therapy}

The enzyme replacement therapy (ERT) with elosulfase alfa (Vimizim ${ }^{\circledR}$, BioMarin Pharmaceutical Inc. (San Rafael, CA, USA); 2 mg/kg weekly) was initiated at the age of 24 months. An oral H1-blocker (Xyzal ${ }^{\circledR}$, GlaxoSmithKline K.K (London, UK); $1.25 \mathrm{mg} /$ dose) was used as premedication to avoid an allergic reaction. A regular administration was performed intravenously for 25 months, with a total of five missed doses; no adverse events were observed.

\section{Clinical Findings Before and After Initiation of the ERT}

To evaluate the clinical effects of the ERT, the following information was collected: body weight, height and physical activities (monthly), blood tests (bimonthly), a whole body X-ray and spinal MRI (at 6 month intervals); echocardiography and abdominal echography (yearly). The findings are summarized in Table 2. 
Table 2. The clinical course of a Japanese boy with MPS IVA.

\begin{tabular}{|c|c|c|c|c|}
\hline & Before & 6 Months after ERT & $\begin{array}{c}12 \text { Months after } \\
\text { ERT }\end{array}$ & $\begin{array}{c}25 \text { Months after } \\
\text { ERT }\end{array}$ \\
\hline Body height & $79 \mathrm{~cm}(-2.3 \mathrm{SD})$ & $81 \mathrm{~cm}(-2.5 \mathrm{SD})$ & $85.5 \mathrm{~cm}(-2 \mathrm{SD})$ & $88 \mathrm{~cm}(-2.9 \mathrm{SD})$ \\
\hline Urine $\mathrm{KS}(\mu \mathrm{g} / \mathrm{g} \cdot$ creatinine $)$ & 66.24 & - & 41.71 & - \\
\hline Walk & $4 \sim 5$ steps & Walk longer and Trot & $50 \mathrm{~m}$ for $6 \mathrm{~min}$ & By walker \\
\hline Posture at sitting & $\begin{array}{l}\text { A forward-bend } \\
\text { posture }\end{array}$ & Up and Better posture & Keep better posture & $\begin{array}{l}\text { Slight forward } \\
\text { tilting posture }\end{array}$ \\
\hline Kyphosis angle (degree) & 126 & 131 & 141 & 138 \\
\hline Shoulder joint mobility & $\begin{array}{l}\text { Disability of } \\
\text { elevation }\end{array}$ & $\begin{array}{l}\text { Improve of elevation } \\
\text { (ball playing) }\end{array}$ & $\begin{array}{c}\text { Keep elevation } \\
\text { (shoulder } \\
\text { backpack) }\end{array}$ & Keep elevation \\
\hline $\begin{array}{l}\text { Spinal compression at } \\
\text { foramen magnum }\end{array}$ & $\begin{array}{l}\text { Compression by } \\
\text { magnetic resonance } \\
\text { imaging (MRI) } \\
\text { No symptom }\end{array}$ & - & $\begin{array}{c}\text { Compression by } \\
\text { MRI } \\
\text { No symptom }\end{array}$ & $\begin{array}{l}\text { Improvement after } \\
\text { decompression } \\
\text { surgery }\end{array}$ \\
\hline Echocardiography & MR trivial & MR trivial & MR trivial & MR trivial \\
\hline Abdominal echography & Hepatosplenomegaly- & - & - & - \\
\hline Otolaryngeography & $\begin{array}{l}\text { Otitis media }+ \text { Mild } \\
\text { deafness }(40 \mathrm{Db})\end{array}$ & Otitis media+ & $\begin{array}{l}\text { Otitis media- } \\
\text { Improved }\end{array}$ & $\begin{array}{l}\text { No medication } \\
\text { Hearing test: } \\
\text { normal( } 25 \mathrm{Db})\end{array}$ \\
\hline Opthalmology & Not particular & - & Not particular & Not particular \\
\hline Communication level & Several words & Short talk & Talk well & Communicate well \\
\hline
\end{tabular}

Abbreviations: mitral valve regurgitation (MR).

\subsection{Urinary GAG Analysis and Other Laboratory Tests}

After 12 months of the ERT, the urine KS decreased from 66.24 to $41.71 \mu \mathrm{g} / \mathrm{g} \cdot \mathrm{creatinine}$. The blood KS levels were not evaluated either before or after the ERT. The regular blood tests revealed no abnormal findings, including markers for bone metabolism, such as alkaline phosphatase (ALP) and cross-linked n-telopeptides of type 1 collagen (NTx) in serum. The specific antibodies for the elosulfase alfa (analyzed by BioMarin Japan K.K), after 6 months of administration, showed a positive result of 90.0 dilution factor (normal range, $<10$ ), but the neutralizing antibody for the elosulfase alfa remained negative. We also evaluated the patient's growth hormone (GH) level throughout the follow-up period. The GH level results remained consistently within the normal range, including the arginine-loading dynamic test (peak GH level of $14 \mathrm{ng} / \mathrm{mL}$, normal range $\geq 6 \mathrm{ng} / \mathrm{mL}$ ).

\subsection{Body Height and Weight}

We measured the patient's body height in the lying position. He showed a short stature $(-2.5$ $\mathrm{SD}$ on the growth chart for Japanese boys) and a lower velocity of body height $(+4 \mathrm{~cm}$ per year) at the beginning of the ERT. His growth improved to -2 SD on the growth chart after 9 months of treatment-he gained $+6 \mathrm{~cm}$ during the first year of ERT (Figure 4). Based on a comparison with the growth chart for male patients with MPS IVA [16,17], the patient's height increased from the 10th percentile to 25 th percentile in 1 year. His body weight gained remained at $-1 \mathrm{SD}$. His posture and spinal alignment were both improved in that period. However, the patient's height gain during the second year on ERT slowed down to $2 \mathrm{~cm}$. 


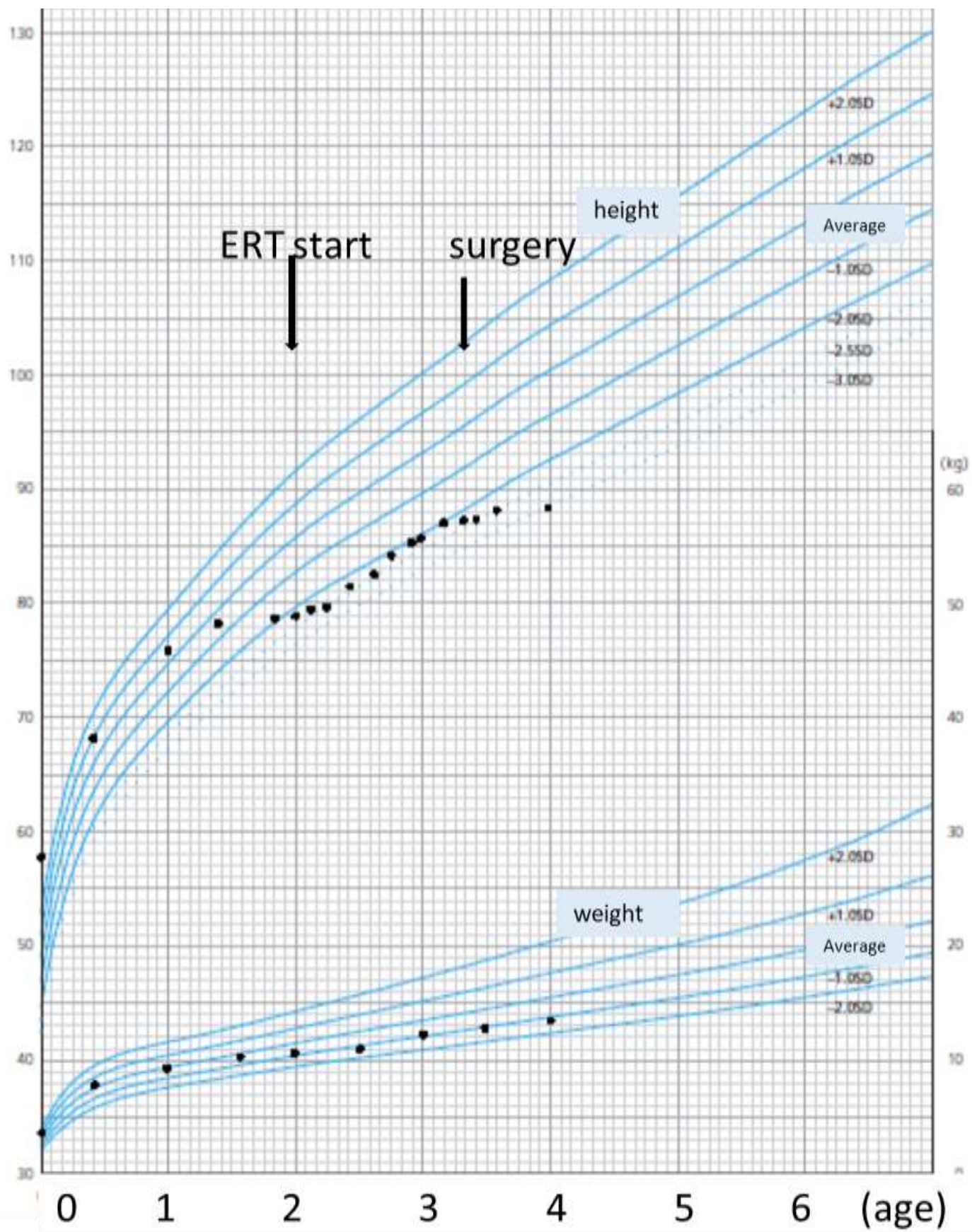

Figure 4. The growth curve of a Japanese boy with MPS IVA. The declining growth velocity of height improved after the initiation of the ERT at the age of 24 months. This chart was referenced from [18].

\subsection{Physical Activity}

At first, the 6 min walk test could not be used to assess our patient. Twelve months after the initiation of the ERT, he could walk $50 \mathrm{~m}$ in $6 \mathrm{~min}$, with one hand held by his mother. He was also able to trot, raise his arm higher for ball playing, and carry his backpack by himself. However, in the second year on ERT, he appeared to stumble easily during walking, leading to the use of a walker.

\subsection{Spinal Lesions}

The spinal cord compression progressed at the level of C1 (Figure 5); the patient gradually developed leg paralysis and ankle clonus during the second year on ERT. At the age of 41 months, a 
cervical X-ray showed atlantoaxial joint instability, which indicated the need for surgery. We detected the progression of spinal cord compression at the level of C1 in an MRI. The patient gradually exhibited leg paralysis and poor gains in body height and weight in the second year after the ERT. Therefore, we performed the surgery on the cervical spine at 17 months after the ERT. Ordinarily, occipitocervical spine fusion with $\mathrm{C} 1$ posterior decompression is performed for patients with MPS IVA. However, as the patient was only 3 years and 5 months of age, the bony structures of the spine were too small to insert the instruments. Accordingly, we decided to first perform the decompression surgery, then perform fusion surgery with instrumentation after the bony structures matured. During general anesthesia, the patient did not exhibit difficulty in securing the airway. Intraoperatively, the posterior arch of $\mathrm{C} 1$ was resected, to release the compression of the spinal cord, by using a surgical microscope under the spinal cord for monitoring. The dura mater at the level of compression was covered with fibrous tissue and the resected lesion consisted of cartilage. The decompression findings of the spinal cord were detected by using intraoperative ultrasonography. No complications were detected during the perioperative period. The patient began rehabilitation and continued careful follow-up, as well as the ERT.

A : 2 years old

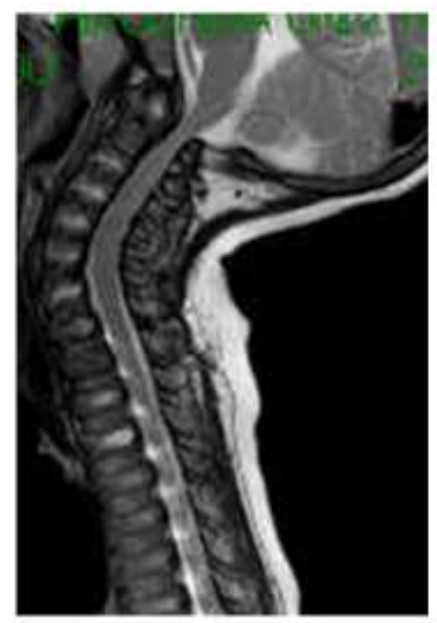

B: 3 years old before the surgery

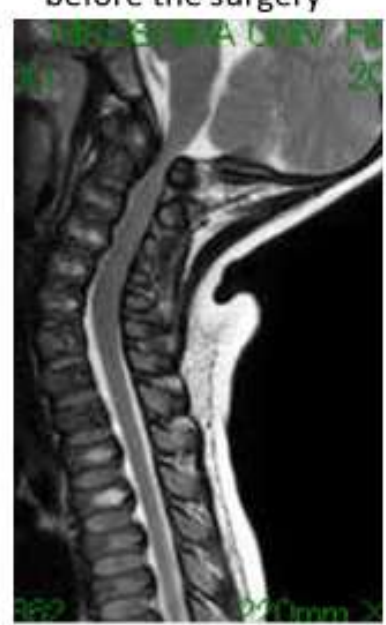

C: 4 years old after the surgery

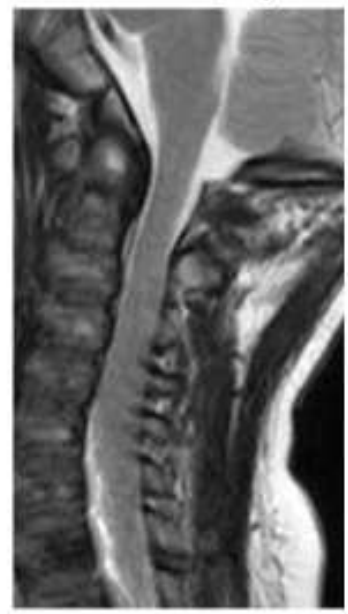

Figure 5. The changes in MRI findings. (A) The spinal cord compression at C1 level was already present at the first examination. (B) The lesion was slowly progressive after the ERT started, (C) which was relieved by resecting the posterior arch of the atlas vertebra.

\subsection{Echography and Management in the Other Departments}

We performed abdominal and cardiac echography before the ERT and once per year thereafter. Hepatosplenomegaly was not observed. The echocardiography showed trivial mitral valve regurgitation, but no changes before and after the ERT. The serous otitis media and the mild hearing loss that had been present before ERT were improved after the age of 3 years. No complications were present in the ophthalmic and dental evaluations.

\section{Discussion}

Patients with classical MPS IVA exhibit severe skeletal dysplasia and growth disturbance, which affect the respiratory function and cause neurological symptoms, due to the spinal cord compression [19]. The pathophysiology of classical MPS IVA is induced by the accumulation of GAG that is not degraded properly in various organs. The accumulation of GAG reportedly interferes with growth factor production, induces inflammation, and enhances programmed cell death [20]. Systemic skeletal dysplasia and related clinical features are caused by a disruption in the cartilage and its extracellular 
matrix, leading to a growth imbalance [3,21]. The accumulation of structurally abnormal GAG, such as KS, leads to a direct effect on chondrocyte differentiation [22].

Elosulfase alfa was previously reported to increase the walking distance and muscle strength in patients with MPS IVA. We speculate that the muscle strength improvement by the ERT led to an improved posture and spinal alignment in this patient. These effects were observed in the first year on ERT. However, our patient showed a progression of spine lesions on ERT, which provoked the symptoms of spinal cord compression. It is suggested that the present ERT agent, generally, could reach the bone tissues far less than other visceral organs and tissues. In addition, the worsening of the muscle phenotype may be caused by the low or absent brain tissue targeting. In order to prevent irreversible spinal damage, it is important to evaluate the neurological findings, muscle strength and activities in the patient's daily life, in addition to a regular spinal MRI.

Our patient exhibited adequate growth to reach -2 SD during the first year of the ERT. Similar effects of ERT on growth have been reported previously for other patients with MPS of various types. Notably, the growth velocity was poor in the second year, compared with that in the first year. The pathogenesis of short stature in patients with MPS of various types is not completely understood; however, the progressive accumulation of GAG in the cartilage and bones has been identified as the underlying cause of bone abnormalities [23]. Futhermore, GAG storage reportedly induces a complex cascade of secondary and tertiary effects, leading to inflammation and cartilage cell apotosis, thus resulting in a poorly organized and metabolically abnormal connective tissue matrix [24]. In addition, the progression of the severe spinal cord compression in our patient was presumably related to poor growth in the second year because the patient showed a mild loss of appetite with no change in body weight and height, especially in the 3 months before the surgery. We speculate that the progression of the severe spinal compression impaired his appetite, which partially affected his growth in the second year on ERT. Therefore, the combined management with orthopedic surgeons was necessary, despite treatment with the ERT. Moreover, recombinant GH replacement therapy was recently reported to improve body height in a patient with MPS IVA and GH deficiency [25]. We found that GH levels remained within the normal range in our patient. Because it has been reported that patients with MPS IVA exhibit low levels of GH during a long-term clinical follow-up, we will continue to assess the GH level in our patient. A long-term observation is required for the physical growth of the patient.

Our patient tolerated weekly ERT without adverse events, since initiation at as early as 2 years old. A more considerate treatment plan with a shorter infusion time, as well as encouragement of the efforts of the patient and the patient's family, is important during ERT for younger patients. Monitoring of the elosulfase alfa dose by using the urine KS will facilitate more precise management, although it was performed only once in this patient, where the urine KS decreased by nearly $40 \%$ after the ERT. Research is underway regarding new therapies (e.g., pentosane polysulfate) and improvements to existing drugs (e.g., immobilized ERT on nanostructured lipid systems) [26,27]. It is expected that a combination of these drugs can achieve better prognosis for patients with MPS IVA.

\section{Conclusions}

In conclusion, we have described a 2 year old patient with classical MPS IVA. The enzyme replacement therapy was well tolerated and the patient exhibited an improvement in visceral symptoms. However, skeletal disorders and their associated nervous disorders should be carefully evaluated by a multidisciplinary medical team that includes orthopedic surgeons.

Author Contributions: A.N.-U. and T.N, wrote drafted the initial manuscript, and A.N.-U., G.T. and S.O. reviewed and revised the manuscript. A.N.-U., R.K., S.K., S.S. and F.S. performed ERT and pediatric management. T.N. performed the orthopedics management and spinal decompression surgery. C.T. and Y.M. provided the confirmed radiological findings about MPS patients. T.I. performend the management of otolaryngology. All authors have read and agreed to the published version of the manuscript.

Funding: This research was supported by AMED under Grant Number 19gk0110040h0001. 
Acknowledgments: We would like to thank Dr. Torayuki Okuyama, Dr. Motomichi Kosuga, and Dr. Asami Hirakiyama (Department of Clinical Laboratory Medicine, National Center for Child Health and Development, Tokyo, Japan) for assay of GalNac6S activity in leukocytes and genetic analysis of GALNS. We also thank BioMarin Japan K.K for arrangement about the measurement of urinary keratan sulfate and specific antibody for Vimizim ${ }^{\circledR}$. We thank Ryan Chastain-Gross, Ph.D., from Edanz Group (https://en-author-services.edanzgroup.com) for editing a draft of this manuscript.

Conflicts of Interest: We declare no conflict of interest. Any role of the funding sponsors in the choice of research project, design of the study, in the collection, analyses or interpretation of data.

\section{Abbreviations}

$\begin{array}{ll}\text { N-acetylgalactosamine-6-sulfatase } & \text { GalNac6S } \\ \text { MPS } & \text { mucopolysaccharidosis } \\ \text { GAG } & \text { glycosaminoglycan } \\ \text { KS } & \text { keratan sulfate } \\ \text { ERT } & \text { enzyme replacement therapy } \\ \text { SD } & \text { standard deviation } \\ \text { MRI } & \text { magnetic resonance imaging } \\ \text { GH } & \text { growth hormone }\end{array}$

\section{References}

1. Khan, S.; Alméciga-Díaz, C.J.; Sawamoto, K.; Mackenzie, W.G.; Theroux, M.C.; Pizarro, C.; Mason, R.W.; Orii, T.; Tomatsu, S. Mucopolysaccaridosis IVA and glycosaminoglycans. Mol. Genet. Metab. 2017, 120, 78-95. [CrossRef] [PubMed]

2. Gentili, C.; Cancedda, R. Cartilage and bone extracellular matrix. Curr. Pharm. Des. 2009, 15, $1334-1348$. [CrossRef] [PubMed]

3. Perache, H.; Sawamoto, K.; Averill, L.; Kecskemethy, H.; Therou, M.; Thacker, M.; Nagao, K.; Pizarro, C.; Mackenzie, W.; Kobayashi, H.; et al. Molecular genetics and metabolism special edition: Diagnosis and prognosis of mucopolysaccharidosis IVA. Mol. Genet. Metab. 2018, 125, 18-37. [CrossRef] [PubMed]

4. Aliiston, T. Chondroitin sulfate and growth factor signaling in the skeleton: Possible link to MPS VI. J. Pediatr. Rehabil. Med. 2010, 3, 129-138. [CrossRef] [PubMed]

5. Muhlebach, M.S.; Wooten, W.; Muenzer, J. Respiratory manifestations in mucopolysaccharidoses. Pediatr. Respir. 2011, 12, 133-138. [CrossRef] [PubMed]

6. Tomatsu, S.; Averill, L.W.; Sawamoto, K.; Mackenzie, W.G.; Bober, M.B.; Pizarro, C.; Goff, C.J.; Xie, L.; Orii, T.; Theroux, M. Obstructive airway in Morquio A syndrome, the past, the present and the future. Mol. Genet. Metab. 2016, 117, 150-156. [CrossRef]

7. Bank, R.A.; Groener, J.E.; van Gemund, J.J.; Maaswinkel, P.D.; Hoeben, K.A.; Schut, H.A.; Everts, V. Deficiency in N-acetylgalactosamine-6-sulfate sulfatase results in collagen perturbations in cartilage of Morquio syndrome A patients. Mol. Genet. Metab. 2009, 97, 196-201. [CrossRef]

8. Tomatsu, S.; Mackenzie, W.G.; Theroux, M.C.; Mason, R.W.; Thacker, M.M.; Shaffer, T.H.; Montaño, A.M.; Rowan, D.; Sly, W.; Alméciga-Díaz, C.J.; et al. Current and emerging treatments and surgical interventions for Morquio A syndrome: A review. Res. Rep. Endocr. Disord. 2012, 12, 65-77. [CrossRef]

9. Tomatsu, S.; Mackenzie, W.G.; Theroux, M.C.; Mason, R.W.; Thacker, M.M.; Shaffer, T.H.; Montaño, A.M.; Rowan., D.; Sly, W.; Alméciga-Díaz, C.J.; et al. Mucopolysaccharidosis type IVA (Morquio A disease): Clinical review and current treatment. Curr. Pharm. Biotechnol. 2011, 12, 931-945. [CrossRef]

10. Tomatsu, S.; Montaño, A.M.; Nishioka., T.; Gutierrez, M.A.; Peña, O.M.; Tranda Firescu, G.G.; Lopez, P.; Yamaguchi, S.; Noguchi, A.; Orii, T. Mutation and polymorphism spectrum of the GALNS gene in mucopolysaccharidosis 4A. Hum. Mutat. 2005, 26, 500-521. [CrossRef]

11. Hiramatsu, M.; Nakamura, K. Elosulfase alfa enzyme replacement therapy attenuates disease progression in a non-ambulatory Japanese patient with Morquio A syndrome (case report). Mol. Genet. Metab. Rep. 2017, 13, 76-79. [CrossRef] [PubMed]

12. Jones, S.A.; Bialer, M.; Parini, R.; Martin, K.; Wang, H.; Yang, K.; Shaywitz, A.J.; Harmatz, P. Safety and clinical activity of elosulfase alfa in pediatric patients with Morquio A syndrome (mucopolysaccharidosis IVA) less than 5 y. Pediatr. Res. 2015, 78, 718-722. [CrossRef] [PubMed] 
13. Do Cao, J.; Wiedemann, A.; Quinaux, T.; Battaglia-Hsu, S.F.; Mainard, L.; Froissart, R.; Bonnemains, C.; Ragot, S.; Leheup, B.; Journeau, P.; et al. 30 months follow-up of an early enzyme replacement therapy in a severe Morquio A patient: About one case. Mol. Genet. Metab. Rep. 2016, 9, 42-45. [CrossRef] [PubMed]

14. Doherty, C.; Stapleton, M.; Piechnik, M.; Mason, R.W.; Mackenzie, W.G.; Yamaguchi, S.; Kobayashi, H.; Suzuki, Y.; Tomatsu, S. Effect of enzyme replacement therapy on the growth of patients with Morquio A. J. Hum. Genet. 2019, 64, 625-635. [CrossRef]

15. Kosuga, M.; Mashima, R.; Hirakiyama, A.; Fuji, N.; Kumagai, T.; Seo, J.H.; Nikaido, M.; Saito, S.; Ohno, K.; Sakuraba, H.; et al. Molecular diagnosis of 65 families with mucopolysaccharidosis type II (Hunter syndrome) characterized by 16 novel mutations in the IDS gene: Genetic, pathological, and structural studies on iduronate-2-sulfatase. Mol. Genet. Metab. 2016, 118, 190-197. [CrossRef]

16. Montano, A.M.; Tomatsu, S.; Brusius, A.; Smith, M.; Orii, T. Growth charts for patients affected with Morquio A disease. Am. J. Med. Genet. Part A 2008, 146, 1286-1295. [CrossRef]

17. Tomatsu, S.; Montaño, A.; Oikawa, H.; Giugliani, R.; Harmatz, P.; Smith, M.; Suzuki, Y.; Orii, T. Impairment of Body Growth in Mucopolysaccharidoses. In Handbook of Growth and Growth Monitoring in Health and Disease; Preedy, V.R., Ed.; Springer Science \& Business Media, LLC: New York, NY, USA, 2012; pp. 2091-2116. [CrossRef]

18. Kato, N.; Isojima, G.; Murata, M. Growth standard charts for Japanese children with mean and standard deviation (SD) values based on the year 2000 national survey. Clinic Pediatr. Endocrinol. 2016, 25, 71-76. [CrossRef]

19. Charrow, J.; Alden, T.D.; Breathnach, C.A.; Frawley, G.P.; Hendriksz, C.J.; Link, B.; Mackenzie, W.G.; Manara, R.; Offiah, A.C.; Solano, M.L.; et al. Diagnostic evaluation, monitoring, and perioperative management of spinal cord compression in patients with Morquio syndrome. Mol. Genet. Metab. 2015, 114, 11-18. [CrossRef]

20. Simonaro, C.M.; D'Angelo, M.; He, X.; Eliyahu, E.; Shtraizent, N.; Haskins, M.E.; Schuchman, E.H. Mechanism of glycosaminoglycan-mediated bone and joint disease; implications for the mucopolysaccharidoses and other connective tissue disease. Am. J. Pathol. 2008, 172, 112-122. [CrossRef]

21. Matalon, R.; Arbogast, B.; Justice, P.; Brandt, I.K.; Dorfman, A. Morquio's syndrome: Deficiency of a chondroitin sulfate N-acetylhexosamine sulfate sulfatase. Biochem. Biophys. Res. Commun. 1974, 61, 759-765. [CrossRef]

22. Doherty, C.; Averill, L.W.; Theroux, M.; Mackenzie, W.G.; Pizarro, C.; Mason, R.W.; Tomatsu, S. Natural history of Morquio A patient with tracheal obstruction from birth to death. Mol. Genet. Metab. Reports. 2018, 1, 59-67. [CrossRef] [PubMed]

23. Melbouc, M. Growth impairment in mucopolysaccharidoses. Mol. Genet. Metab. 2018, 124, 1-10. [CrossRef] [PubMed]

24. Simonaro, C.M.; Ge, Y.; Eliyahu, E.; He, X.; Jepsen, K.J.; Schuchman, E.H. Involvement of the Toll-like receptor 4 pathway and use of TNF-alpha antagonists for treatment of the mucopolysaccharidoses. Proc. Natl. Acad. Sci. USA 2010, 107, 222-227. [CrossRef] [PubMed]

25. Cattoni, A.; Motta, S.; Masera, N.; Gasperini, S.; Rovelli, A.; Parini, R. The use of recombinant human growth hormone in patients with Mucopolysaccharidosis and growth hormone deficiency: A case series. Ital. J. Pediatrics. 2019, 45, 93. [CrossRef] [PubMed]

26. Schuchman, E.H.; Ge, Y.; Lai, A.; Borisov, Y.; Faillace, M.; Eliyahu, E.; He, X.; Iatridis, J.; Vlassara, H.; Striker, G.; et al. Pentosan polysulfate: A novel therapy for the mucopolysaccharidoses. PLoS ONE 2013, 8, e54459. [CrossRef]

27. Álvarez, J.; Bravo, S.B.; García-Vence, M.; De Castro, M.J.; Luzardo, A.; Colón, C.; Tomatsu, S.; Otero-Espinar, F.J.; Couce, M. Proteomic analysis in Morquio A cells treated with immobilized enzymatic replacement therapy on nanostructured lipid systems. Int. J. Mol. Sci. 2019, 20, 4610. [CrossRef]

(C) 2020 by the authors. Licensee MDPI, Basel, Switzerland. This article is an open access article distributed under the terms and conditions of the Creative Commons Attribution (CC BY) license (http://creativecommons.org/licenses/by/4.0/). 